Article

\title{
Grazing of Dairy Cows in Europe-An In-Depth Analysis Based on the Perception of Grassland Experts
}

\author{
Agnes van den Pol-van Dasselaar ${ }^{1, *}$, Deirdre Hennessy ${ }^{2}\left[\right.$ and Johannes Isselstein ${ }^{3}(\mathbb{C}$ \\ 1 Grassland Science, Aeres University of Applied Sciences, 8251 JZ Dronten, The Netherlands \\ 2 Grassland Science Department, Teagasc, Animal and Grassland Research and Innovation Centre, Moorepark, \\ Fermoy, P61 P302 Co. Cork, Ireland; deirdre.hennessy@teagasc.ie \\ 3 Department of Crop Sciences, Grassland Science and Center of Biodiversity and Sustainable Land Use, \\ Georg-August-Universität Göttingen, 37075 Göttingen, Germany; jissels@gwdg.de \\ * Correspondence: a.van.den.pol@aeres.nl
}

Received: 8 January 2020; Accepted: 3 February 2020; Published: 4 February 2020

\begin{abstract}
Grazing is inherently close to the nature of herbivores, but no longer applied everywhere in Europe. Therefore, the perception of grassland experts on the occurrence, importance, constraints, solutions and future of grazing of dairy cows was studied. The study builds on results from the European Grassland Federation Working Group Grazing in the period 2010-2019. Both surveys and focus group meetings were used. There is a clear trend of reduced grazing in Europe. Since grazing is valued by different stakeholders and provides many ecosystem services, solutions to the constraints to grazing must be found. Constraints can be divided into region specific constraints, farm specific constraints and farmer specific constraints. The solutions include developing new knowledge, bringing the knowledge already available to practice and rewarding farmers for grazing as a service to society. If grazing is not supported, it will further decline. However, a joined endeavour has the potential to make a significant difference in transforming grass-based production systems and stimulating grazing.
\end{abstract}

Keywords: grazing; constraints; support; ecosystem services

\section{Introduction}

Grasslands occupy a vast area of agricultural lands in Europe and grazing systems are important components of the landscape in almost all European countries [1]. Grazing is inherently close to the nature of herbivores. It is the traditional way of ruminant production. Grazing ruminants are capable of transforming grass (a resource that could otherwise not be used by humans) into human edible food and are thus important for food production. As well as producing food, grazing systems deliver a large number of other ecosystem services. Grazing systems contribute to, e.g., soil carbon sequestration, biodiversity, beauty of the landscape, maintaining populations in rural areas, conservation of soil quality and supply of feed protein at farm level [2]. The increasing global demand for meat and milk, environmental concerns about the sustainability of intensive production systems, and consumer expectations favour an increasing role for production systems based on grazing in the future. These grassland-based systems are likely to be more environmentally sound, economically viable, productive and efficient with respect to scarce inputs [3,4].

There are no readily available data on the developments in grazing of dairy cows in Europe. Grazing is not monitored explicitly at a European level. It is, however, generally agreed that in the last decades a trend towards less grazing is visible throughout Europe. This was first reported in a review paper on grazing [5] and was one of the factors resulting in the creation of a Working Group "Grazing" 
within the European Grassland Federation. Various considerations play a role in the decision to graze or not to graze [5]. These include:

- Technical factors related to the set-up and organisation of the farm (e.g., available land area, soil type, infrastructure, fragmentation) [4];

- Economic factors (e.g., productivity, production costs, labour) [6];

- Social factors that have to do with the intrinsic motivation and the mind-set of the farmer [7].

The latter factors (social) are particularly important when determining measures to encourage outdoor grazing. It is indeed the farmer who decides whether the animals go outside for grazing or not. The degree of grazing is determined not only by the characteristics of the farm, but also by the characteristics of the farmer [8]. This has also been demonstrated under German and Dutch conditions $[7,9]$ where the attitude and mind-set of the farmer towards grazing was a major factor influencing the degree of grazing.

There is a lack of understanding of the constraints to adopting or practicing grazing at farm level. The question of whether to graze or not to graze is obviously controlled by high-level interactions among the factors mentioned above. Classical approaches to analysing or researching those complex situations (e.g., experimental farms or meta-analyses) fail in answering this question [10-12]. Alternative methods are required. Therefore, this study used a focus group approach as a strategy to collect data. Such an approach has proven to be effective for uncovering and understanding attitudes and opinions [13] and has been used before in agricultural research, e.g., [10]. The study aims to identify the perception of grassland experts with respect to (1) the occurrence of grazing in Europe, (2) the importance of grazing in the farm system, (3) the constraints for farmers, (4) the support needed to overcome these constraints, and (5) the future of grazing.

\section{Materials and Methods}

\subsection{Procedure}

The Working Group "Grazing" (WG Grazing) of the European Grassland Federation (EGF) was used as a source of information for this study. It provides a good platform for a focus group approach. Since 2008, topics at the WG Grazing meetings have covered the full practice of livestock grazing in Europe, as well as new research and recent achievements. Furthermore, its members include a wide range of experts, from applied to fundamental, from all regions of Europe. The WG Grazing employs different methodologies (surveys, expert forums, stakeholder groups, etc.). Therefore, it embodies a unique opportunity to improve our knowledge, develop a common understanding, and provide ideas and pathways for the future. The following topics and methods were used for this study:

1. Occurrence of grazing: surveys among members of the WG Grazing;

2. Importance of grazing: surveys among members of the WG Grazing;

3. Constraints for farmers: focus group meetings of the WG Grazing;

4. Support needed to overcome these constraints: focus group meetings of the WG Grazing;

5. Future of grazing: surveys among members and focus group meetings of the WG Grazing.

\subsection{EGF Working Group "Grazing"}

The WG Grazing is a Working Group of the European Grassland Federation (https://www. europeangrassland.org/en/). The aim of the WG Grazing is to exchange knowledge on all aspects of grazing research and to provide a forum for networking. Everyone that expresses his or her interest in grass and grazing is welcome as a group member. The members come from science, both applied and fundamental science, extension services, practice and education. The WG Grazing ensures detailed knowledge exchange and discussion on grazing. It also monitors the state-of-the art with respect to grazing of dairy cows in Europe. The group was established in Uppsala, Sweden at the General 
Meeting of the EGF in 2008. Thus far, six physical meetings have been held (Table 1). Other activities have been surveys among the members of the group.

Table 1. Meetings of the Working Group “Grazing” (WG Grazing).

\begin{tabular}{cccc}
\hline Year & Country & Number of Participants & Number of Countries Present \\
\hline 2010 & Germany & 42 & 15 \\
2012 & Poland & 29 & 13 \\
2014 & UK & 40 & 16 \\
2015 & The Netherlands & 59 & 16 \\
2016 & Norway & 52 & 14 \\
2018 & Ireland & 100 & 18 \\
\hline
\end{tabular}

\subsection{Surveys}

Since the first meeting of the WG Grazing, six surveys (in 2010, 2011, 2014, 2016, 2018, and 2019) on the extent of grazing in different European countries have been conducted among members of the WG Grazing. Members were asked what percentage of dairy cows graze in their country. It should be noted that answers to these questions could be based either on data or on personal experiences of the members, i.e., their perception. When the answers are based on their perception, they can be described as educated guesses. An educated guess is a guess that is based on a certain amount of knowledge and is therefore likely to be correct. Next to the results of the surveys (2010-2019), there are data available on the extent of grazing in the period 2001-2008 for three countries (Denmark, Ireland, the Netherlands). These data are based either on educated guesses (Denmark, Ireland) or on statistical data (the Netherlands) and have been published previously [5].

In the years 2016, 2018 and 2019, an on-line survey on grazing (Appendix A) was developed using SurveyMonkey (www.surveymonkey.com) and shared with the members of the WG Grazing. Next to questions related to the organization of the meetings, there were questions to get a better insight into the perception of the members and the opinion of the members on a number of issues:

1. Extent of grazing (input for the occurrence of grazing);

2. Importance of grazing for different stakeholder groups: farmers, government, scientists, teachers, students, general public, respondents to the survey themselves (input for the importance of grazing);

3. Biggest challenge for grazing in the next decade (input for the future of grazing).

The number of respondents was 88, 92 and 52 for the years 2016, 2018 and 2019, respectively.

\subsection{Focus Group Meetings}

The WG Grazing meetings in 2010 and 2012 were set up as regular scientific conference meetings with plenary presentations followed by the opportunity to ask questions. The set-up changed considerably in 2014. The meetings from 2014, 2015, 2016, and 2018 provided a limited number of short oral presentations. The main part of the meeting consisted of discussion sessions in small groups on predefined topics. During these sessions, a group of respondents focused on 2-3 given topics (Table 2). We used the focus group approach as a method to collect data [13,14]. The focus groups were composed of a roughly equal mix of males and females. The number of focus groups varied between years, but the size of the focus group was always about 10 persons. Each focus group was chaired by a dedicated chairperson, who was randomly appointed by the WG Grazing Organizing Committee (the authors of this paper). Notes of each focus group discussion were taken by a randomly appointed reporter. The notes were intended to capture the overall discussion and were, after a final check by the reporter and the chair of the focus group, sent to the chair of the WG Grazing. For the current paper, the original reports of the individual groups were studied in-depth using a qualitative content analysis to find emerging themes. 
Table 2. Discussion topics and number of focus groups for WG Grazing meetings in 2014 to 2018 of which results are presented in this paper.

\begin{tabular}{|c|c|c|}
\hline Year & Topics & Number and Size of Groups \\
\hline 2014 & $\begin{array}{l}\text { Forward looking views on the future of grazing in } \\
\text { Europe: Why is grazing of dairy cows in some countries } \\
\text { mainstream while in others it is almost a niche system? } \\
\text { Possibilities and constraints of producing milk } \\
\text { on grasslands. } \\
\text { Current and future economics of grazing. Should grazing } \\
\text { be stimulated by (inter)national bodies? Is there a future } \\
\text { for grazing? }\end{array}$ & Four groups of about 10 persons \\
\hline 2015 & $\begin{array}{l}\text { - Grazing and the agricultural European Innovation } \\
\text { Partnership (EIP-AGRI), what do we expect? Why } \\
\text { maintain permanent grassland? Why not? } \\
\text { High yielding herds, increasing farm size, automatic } \\
\text { milking and grazing-is it possible to combine? What are } \\
\text { reasons to stop and what are reasons to continue? } \\
\text { Grazing and automation, what technology is available? } \\
\text { What is the most urgently needed innovation? }\end{array}$ & Five groups of about 10 persons \\
\hline 2016 & $\begin{array}{l}\text { - Our high-tech world: technology versus farmer skills, } \\
\text { ethics, nature/environment and other issues? } \\
\text { High-tech methods: in what areas is there potential to } \\
\text { develop new technologies? What can we learn from } \\
\text { technologies in other disciplines? What is the potential of } \\
\text { technology to improve our understanding of grazing? } \\
\text { How do we overcome problems? } \\
\text { How to reach (young) farmers in a high-tech world? } \\
\text { How to educate young people with respect to grazing? }\end{array}$ & Five groups of about 10 persons \\
\hline 2018 & $\begin{array}{l}\text { - Support of grazing: Do we actually need support for } \\
\text { grazing since grazing is an economic activity? Should we } \\
\text { seek financial support for grazing or should we search for } \\
\text { solutions to make grazing more profitable at farm level? } \\
\text { In what way could this best be organised? } \\
\text { Methods to maximise grazing: What are the main } \\
\text { barriers to maximise grazing and how to overcome these } \\
\text { barriers? How to optimise grazing whilst supporting } \\
\text { other ecosystem services that grasslands provide? }\end{array}$ & 10 groups of about 10 persons \\
\hline
\end{tabular}

\section{Results}

\subsection{The Occurrence of Grazing}

Thus far, the extent of grazing of dairy cows is not monitored in Europe. The surveys among WG Grazing members in the period 2010-2019 provided, for the first time, an insight into the occurrence of grazing of dairy cows in Europe (Table 3). It should be noted that results have been variable and there is no complete overview, but these results do provide insight into the state of the art with respect to grazing in Europe. Sometimes statistical data are available, but usually the numbers provided are only an educated guess, which explains some of the variation between years within a country. Furthermore, in these surveys the amount of grazing can range from full grazing to very limited grazing. Table 3 clearly shows a general trend of less grazing in Europe. 
Table 3. Grazing in Europe (\% dairy cows) in six distinctive regions of Europe. Data from the European Grassland Federation WG Grazing; mainly educated guesses.

\begin{tabular}{|c|c|c|c|c|c|c|}
\hline Region and Country & 2010 & 2011 & 2014 & 2016 & 2018 & 2019 \\
\hline \multicolumn{7}{|l|}{ North } \\
\hline Norway & & & & 90 & $80-85$ & 80 \\
\hline Sweden & 100 & 100 & 100 & 100 & 100 & 100 \\
\hline Finland & & & & 70 & 60 & 80 \\
\hline \multicolumn{7}{|l|}{ West } \\
\hline Ireland & 99 & 99 & 98 & 95-100 & 95-100 & $95-100$ \\
\hline UK & & & & $80-90$ & $80-95$ & $70-80$ \\
\hline \multicolumn{7}{|l|}{$\underset{\text { grazing }>50 \%}{\text { Central; }}$} \\
\hline The Netherlands ${ }^{1}$ & 74 & 71 & 69 & 65 & 71 & $65-85$ \\
\hline Belgium $^{2}$ & $85-95$ & & $75-80$ & $60-85$ & $40-95$ & $30-95$ \\
\hline Luxembourg & $75-85$ & & 73 & 75 & 75 & \\
\hline France & & 90-95 & 90 & $75-95$ & $70-95$ & 90 \\
\hline Switzerland & & $85-100$ & $75-90$ & $80-97$ & $75-95$ & $70-90$ \\
\hline \multicolumn{7}{|l|}{$\underset{\text { grazing }<50 \%}{\text { Central; }}$} \\
\hline $\begin{array}{c}\text { Denmark } \\
\text { Dent }\end{array}$ & $35-45$ & $30-35$ & $25-30$ & 25 & $20-30$ & $20-25$ \\
\hline Germany & 42 & & & $10-50$ & $20-42$ & $15-40$ \\
\hline Austria & & 25 & & 40 & 44 & 44 \\
\hline \multicolumn{7}{|l|}{ East } \\
\hline Poland & & & & 20 & 20 & 30 \\
\hline Estonia & & 35 & & & & 10 \\
\hline Lithuania & & & $50-70$ & & 75 & \\
\hline Czech Republic & 20 & & & 3 & 5 & \\
\hline Bosnia Herzegovina & & 5 & & & & \\
\hline Slovenia & 25 & & & 20 & $20-40$ & $20-40$ \\
\hline Hungary & & & & $2-3$ & $3-5$ & $3-5$ \\
\hline Bulgaria & & & & 50 & & \\
\hline \multicolumn{7}{|l|}{ South } \\
\hline Portugal & 50 & & & & & 60 \\
\hline (NW) Spain & 20 & & 18.5 & $10-30$ & 20 & $20-30$ \\
\hline Greece & 15 & $<10$ & & 10 & 15 & 10 \\
\hline Italy & & & & $10-20$ & $10-30$ & \\
\hline
\end{tabular}

$1 \longdiv { \text { Statistical data in 2010-2018 [15], educated guess in 2019. } { } ^ { 2 } \text { Huge regional differences between Flanders } }$ and Wallonia.

\subsection{The Importance of Grazing}

The opinion of the WG Grazing members on the importance of grazing for a large group of stakeholders was obtained via surveys. Analysis of the results of the surveys showed that the opinion of the experts did not significantly change in the period 2016-2019, and therefore averages are shown in Table 4.

Table 4. Opinion of grassland experts of the WG Grazing on the importance of grazing for different stakeholder groups (\% respondents that scaled importance in categories 1-3, 4-7 and 8-10 on a scale of 1 to 10 , where 1 was unimportant and 10 was important; average for $2016(\mathrm{~N}=88), 2018(\mathrm{~N}=92)$ and $2019(\mathrm{~N}=52))$.

\begin{tabular}{cccc}
\hline Stakeholder Group & $\mathbf{1 - 3}$ & $\mathbf{4 - 7}$ & $\mathbf{8 - 1 0}$ \\
\hline Students & 10 & 63 & 28 \\
Teachers & 9 & 62 & 29 \\
Farmers & 13 & 56 & 31 \\
Government & 14 & 45 & 42 \\
Scientists & 6 & 47 & 46 \\
General public & 3 & 32 & 64 \\
Respondents to the & 1 & 15 & 83 \\
survey themselves & & & \\
\hline
\end{tabular}


Grazing was considered important for all stakeholder groups identified. The experts identified especially the general public as a stakeholder group that considers grazing of high importance. Furthermore, the respondents themselves valued grazing relatively high. This was to be expected since they are all interested in grazing. Differences between different countries were limited, although there was a trend that countries with high percentages of grazing (Table 3) were a bit more positive about the importance of grazing for all stakeholder groups.

\subsection{The Constraints to Grazing for Farmers}

Analysis of the reports of the focus group meetings revealed three main streams of constraints: constraints that were related to the characteristics of different regions, constraints that were related to characteristics of farms and constraints that were related to characteristic of farmers. Even though in all focus group meetings all three types of constraints were mentioned, it was striking that in 2018, farmer specific constraints received much more attention than in the previous years. They are getting a more prominent place.

\subsubsection{Region Specific Constraints}

The following potential region specific constraints were identified by the WG Grazing members:

- Climate conditions, e.g., under hot conditions with low rainfall, grass stops to grow leading, for example, to reduced or no summer growth in South Europe.

- Abiotic site conditions like topography, e.g., some mountains are too steep to graze.

- Length of the growing season, e.g., Ireland can rely on grazing during the majority of the year, while, e.g., Sweden has a short growing season.

- Soil type, e.g., in some regions soil type prevents extended grazing, e.g., peat soils.

- Culture, tradition, heritage, history, e.g., in countries like the Netherlands and Sweden, the knowledge about good grazing practice has not been passed on or taught to farmers and advisors for the last three or four decades, advisors mainly focussed on barns; Hungary lost the tradition of grazing during the communist era.

- Market and prices, e.g., there is no market for products based on grazing; also different price relations of milk, concentrates, land, labour, etc. in different regions.

\subsubsection{Farm Specific Constraints}

The most important farm specific constraints identified by the WG Grazing members were:

- Infrastructure of the farm. This is considered the most important constraint to grazing for farmers. Grazing animals need enough land area near the barn. Fragmented land areas are not suitable.

- Large herds. This constraint is related to the previous one, since large herds need bigger grazing platforms. Often the herd size of a farm increases without an increase in grazing platform.

- Automatic milking systems (AMS). AMS is seen as a constraint, since the cows need to be able to go from the grazing platform to the AMS continuously.

- Difficult to adapt high production cows to grazing.

- Lack of grazing infrastructure (roadways, fencing, water supply), sometimes considered to be too expensive.

- Weather variability leading to fluctuations in grass supply and grass quality.

- Grass supply, grass quality and grass intake per cow are unknown, therefore supplementation not well adapted.

- Cow genotype not suited for grazing; modern cows are not adapted to grazing.

- Environmental problems, e.g., more nitrate leaching as a result of grazing.

- Less advise available for farmers who want to graze due to many technical and salespeople promoting non-grazing systems. 


\subsubsection{Farmer Specific Constraints}

The farmer specific constraints identified by the WG Grazing members were related to:

- Attitude; e.g., members mentioned that "grazing is economically profitable, but not perceived like that"; "among farmers, research and policy there are different perceptions about the benefits of grazing"; "farmers are not motivated to graze"; "it deals with the mind of farmers, this is related to personal perception of life comfort, personal motivation and preferences and the way farmers are locked in their current system".

- Culture; e.g., in some areas grazing is perceived as old-fashioned and unproductive.

- Social environment; e.g., what is the neighbour doing?

- Social pressure by consumers as a result of public perception of benefits of grazing

- The farmers position in the supply chain, farmers are very dependent on other supply chain actors, particularly retailers.

- Opinion of advisors with a mind-set of keeping animals inside.

- Management capacities: providing grass silage and maize is easier for the farmer than grazing, grazing is complicated.

- Technical skills; e.g., grazing of larger herds and grazing in combination with AMS requires more technical skills, farmers have little information on grazing techniques, lack of confidence around decision making.

- Labour. Daily workload can be perceived as less predictable when animals are on pasture because damaged fences or water troughs must be repaired immediately. A mix of grazing and confinement (e.g., grazing only during the day) needs more labour than a confinement system only, so farmers move away from grazing; the decrease in grazing induces the perception of difficulty in managing it.

- Lack of knowledge and education of farmers.

\subsection{Support to Farmers to Overcome Constraints to Grazing}

When looking at the discussion in the focus group meetings on support to overcome constraints for grazing, three distinct directions were identified: (i) develop new knowledge, (ii) bring available knowledge to farmers, and (iii) reward farmers for grazing.

\subsubsection{Develop New Knowledge}

When discussing new knowledge during the WG meetings, the focus was on technological solutions. Technologies are important, as was illustrated by a WG Grazing member "High tech can be an interesting, 'sexy' tool to record data and reduce the 'annoying' work on the farm. Technology can be interesting for the young farmer. It must save labour and must produce confidence and control". Bottom line is insight into what is happening in pastures and with cows, and insight into what to do now or tomorrow or next week. Table 5 provides examples of the many types of technology that were deemed necessary to develop. There were also some comments with respect to technology. Farmers' skills are important in relation to technology. Farmers cannot rely blindly on technology without knowing what the outcome should approximately be. Technology can also come with ethical concerns. Technology that disturbs 'normal' cow behaviour should be avoided. The electricity involved with electric fencing can, for example, be a problem. Animals carrying several sensor systems may not be appreciated by society. Manipulation and misuse of data should be avoided (e.g., using data to control individual farmers or using farmers' data in industry instead of for the benefit of farmers). Technology like drones may affect privacy when taking pictures. Technology needs to be standardised (techniques, terms, handling, adaptability to other farm systems). Finally, the innovation capacity with respect to technology should, according to the WG Grazing members, be targeted more to grazing. Currently it seems that technological innovations develop faster in indoor feeding systems than in grazing systems. 
Table 5. Constraints to grazing that could be resolved by technology according to the WG Grazing members.

\begin{tabular}{|c|c|}
\hline Problem/Constraint & Examples of Technology to Be Developed \\
\hline Labour & $\begin{array}{l}\text { Anything that reduces labour, virtual fencing, cow } \\
\text { traffic management, how to motivate cows, drones to } \\
\text { measure grass and to fetch the cows }\end{array}$ \\
\hline Grass intake per individual cow is not known & $\begin{array}{l}\text { Develop predictors, e.g., in the milk, and cow sensors, } \\
\text { e.g., on cow bites, head position, automatic regulation } \\
\text { of supplementary feeding }\end{array}$ \\
\hline Grass supply is not known & Real-time information, use of drones \\
\hline Grass quality is not known & Non-destructive real-time grass quality analyses \\
\hline Data are available, but cannot be translated to advice & Develop advisory systems. Develop rules of thumb \\
\hline Environmental problems & $\begin{array}{l}\text { Precision farming and site-specific management can } \\
\text { lead to better use of nutrients, better managed cutting } \\
\text { and grazing, detection of poisonous plants }\end{array}$ \\
\hline
\end{tabular}

Next to technology, some other research needs were mentioned. Region specific grazing systems need to be developed, e.g., for high output dairy farms or climate adaptive grazing. Knowledge needs to be improved on the interplay between grazing and ecosystem services. Given the (future) challenges of climate changes, new breeds or other grassland species or mixtures are needed to improve resilience. Better weather forecasts would also be helpful. In general, it was stressed that a holistic view is necessary, since grazing is related to all aspects of a farm. Finally, many groups mentioned that it would be good to study the constraints and provide solutions with a group of different actors (researchers, farmers, advisors, business), for example an Operational Group.

\subsubsection{Bring Available Knowledge to Farmers}

The WG Grazing mentioned that there is a lot of knowledge available that does not effectively reach farmers. Therefore, focus should be on improving the knowledge exchange methods. We need "to avoid the loss of grazing skills". Positive effects are expected from:

- Strengthening of the extension system, investments in the extension system to inform and motivate people. More grazing advisors are needed and preferably advisors which are experts in animals and plants. Holistic thinking is necessary in advisory as well, as was said: "we need whole system advisors".

- Discussion groups where farmers learn from farmers, both positive and negative issues. It was said: "Front runners may act as inspiring persons for other farmers".

- Farm visits, preferably in the grazing season in the field to discuss relevant management strategies at that particular time in the season.

- Demonstrations of practical systems with a slight transition towards grazing rather than presenting the ideal grazing system that farmers cannot imagine to realise, for example, adding a few hours of grazing in high output systems; showing small steps may demonstrate that grazing is achievable.

- Improve communication of research results.

- Education must not only focus on the hard facts, but must improve the perception of grazing among farmers. It was said: "In our educational systems, we learned to be securely in control of our environment. By practicing the grazing system, we are out of control. Dynamic adaptation to varying environmental conditions is needed. This needs to be considered and accepted, before applying this system"

- Organising competitions, e.g., a ranking list of best grazers published in all farmers journals, give farmers the opportunity to compare and compete by benchmarking of technical and economic performance. 
- Focus on knowledge transfer of the constraints related to perceived behavioural control, e.g., management capacities, technical skills and perception of labour.

- Provide a basket of fact based options, the farmer needs to have a choice.

- Focus on young farmers, advisors and teachers. It was said: "In contrast to other agricultural fields, young famers know less why and how grassland systems, and grazing systems in particular, should and could be managed with modern technologies. Grazing looks like a black box to them. And don't forget to teach the teachers".

Next to focussing on improving the knowledge exchange methods, WG Grazing members also believe that it is essential to especially transfer knowledge on new technologies to farmers so that they know how to use them. In particular, technologies with a large impact on labour are expected to be easily accepted. Specific technologies mentioned, that are already available for farmers, are cow sensors, breeding technologies (plants and animals) and precision farming techniques. The price of technology is important. One of the focus groups reported, "As long as new technologies are still in the introduction phase, they are not competitive with well-established technologies. The biggest obstacle for introducing new technologies is the acceptance of new technologies by farmers because of the low competitiveness of new technologies compared to established technologies".

Special attention was paid to the combination of automatic milking and grazing during the focus group meeting of 2015. It was concluded that farmers choose automatic milking systems (AMS) to improve their lifestyle and farmers believe that it is more difficult to combine AMS with grazing. However, there are many good examples of farmers that can easily combine AMS and grazing. Furthermore, farmers that work with automation might also be the farmers to easily adopt new technology like automatic measurements of grass, which provides new perspectives. Bringing the available knowledge to farmers is key when it comes to successfully combine grazing and automation.

\subsubsection{Reward Farmers for Grazing}

Members of the WG Grazing discussed possibilities to reward farmers for grazing thereby stimulating grazing. These rewards do not take away the 'hard constraints' (region specific constraints and farm specific constraints), but they are a driver for grazing. Rewards can be divided into financial incentives/initiatives within the market, common agreements to stimulate grazing, and policies/legislation.

Financial incentives/initiatives within the market can be premiums, e.g., grazing premium in the Netherlands (all dairy industry) and regional initiatives, e.g., in France, Luxembourg and Germany. Another option are subsidies, e.g., for semi-natural grasslands, for land consolidation or for improved farm layout (e.g., roadways, water systems, fencing and paddock layout). Finally, consumers can pay extra money for specific products from grazing. For consumers, grazing is the standard, which means that good marketing strategies and engagement with the consumers is necessary. Evidence needs to be provided about a better product, for example dietary effects could be promoted (e.g., improved concentrations of CLA and PUFAs) or ecosystem services delivered (e.g., biodiversity).

Common agreements to stimulate grazing can be treaties on grazing, e.g., the Grazing Treaty in the Netherlands and the Grazing Charta in Germany which are signed by parties in the full dairy chain. However, cooperative thinking also belongs to this-local action plans are developed with a range of stakeholders, including farmers.

Policies / legislation includes laws which make grazing compulsory (e.g., in Sweden), long-term support of ecosystem services like grazing (e.g., via CAP2020), support by (inter)national bodies (e.g., via education and financial support in abandoned areas of Europe) and stimulation of land re-allocation to enlarge grazing platforms. 


\subsection{The Future of Grazing}

WG Grazing members provided an overview of the biggest challenges for grazing in the next decade in the on-line surveys of 2018 and 2019. The biggest challenges were identified as follows: access to land, climate change, knowledge transfer, economy, research and development, sustainability, labour, and the mind-set of farmers. Access to land includes the requirement for a larger grassland area available for the farms due to increasing herd size per farm. Additionally, a key problem is also the fragmentation and scattered allocation of grazing lands. With regard to increasing risks with climate change, grass production will likely be limited by more extreme weather conditions, unpredictable rainfall patterns, increasing frequency of dry spells in spring and early summer, and wet periods in autumn and winter. WG Grazing members identified considerable weaknesses in the knowledge transfer with regard to grazing. In many European countries the farmer's knowledge around grazing has largely diminished. There is a strong need to improve the advisory systems and to pay more attention to teaching at schools and universities. Referring to the economy of grazing, it is not only about costs of production and product prices, i.e., market mechanisms and added value. Similarly, or even more importantly in the view of the experts, is that farmers are often trapped in high debt ratios that do not allow them to switch to grazing. Closely related to knowledge transfer and improved education is the need for more research and development in the field of grazing. This mainly refers to novel technology that supports grazing systems but also to breeding cows that are better adapted to grazing. Grazing in common farming situations in Europe often lacks efficiency of herbage utilisation and poses risks to nutrient losses and greenhouse gas emissions. Thus, the sustainability of grazing systems has to be improved. Furthermore, although grazing has generally the potential to reduce labour requirements on the farm, the nature of the work in conducting grazing is different and skilled labour is often not available. Finally, there is the mind-set of the farmer which might not be sufficiently prepared to switch from in-door feeding to grazing. Reluctant farmers have to be convinced to apply grazing. Criteria of personal success of a dairy farmer have to be changed from maximum yield (revenue-oriented) to an economic productivity of the labour (income-oriented).

The future of grazing has also been a topic in the focus group meetings of the WG Grazing. According to the members, the future of grazing is dependent on development of farms in terms of herd size versus grazing area, environmental regulations and volatility of input and output prices. The current debate on consumption of animal products has been acknowledged, but in general, grazing is seen as positive and important for society. In some regions or some situations, other systems are preferable and that should be accepted. Diversity in management can also support a more diverse landscape, which is good for ecosystem services.

According to the WG Grazing, support for grazing should be region specific, since conditions and constraints for grazing are region specific. Knowledge development and knowledge transfer are important for all regions. Members of the WG Grazing have different opinions on whether or not grazing should be supported by rewarding farmers for grazing. Some state that this is not necessary since it is an economic activity in itself, while others point out that grazing delivers ecosystem services to society that should be rewarded. Again, this varies depending on region. For example, Ireland can rely on grazing during the majority of the year, while, e.g., Sweden has a short growing season. According to WG Grazing members, regions like Ireland where almost all the milk comes from grazing cows, will have little chance for a premium label; however, knowledge transfer remains essential.

\section{Discussion}

\subsection{The Trend for Less Grazing in Europe}

The surveys among WG Grazing members in the period 2010-2019 provided, for the first time, an insight into the occurrence of grazing of dairy cows in Europe and created a unique dataset (Table 3). A global overview of grazing in Europe became available that showed that Europe can be divided into 
six distinctive regions with respect to the extent of grazing and the trends in grazing that have been observed:

- North of Europe: Countries where welfare legislation is a driver for cows being outside for six weeks to four months. While for Norway and Finland, dairy cows in some systems (mainly tie-stalls) are obliged by law to go outside; in Sweden, this is true for all dairy cows. There are no requirements regarding the contribution of pasture to the total energy supply. Cattle must have access to pasture or alternative exercise areas outdoors for a minimum of time during the summer. The length of the grazing period depends on the region: the more north, the shorter the grazing season. In this region of Europe, the percentage grazing is expected to remain high since grazing is required by law. The number of hours that cattle spend outside is, however, decreasing.

- West of Europe: Grass based dairy systems dominate and the percentage of grazing is high, especially in Ireland. In Ireland, grass based seasonal systems of milk production still predominate. The length of the grass-growing season varies from about eight months in the northeast to up to 11 months in the extreme southwest.

- Central Europe, countries with more than 50\% grazing, especially near the North Sea: In this region, the percentage of grazing cows has been decreasing during the last decades. Not only are more and more cows no longer grazing, but also for the cows that graze, the days grazing per year and the number of hours grazing per day are declining. Only recently this development has slowed down due to the introduction of a premium price for 'pasture milk', like in the Netherlands, Belgium and France.

- Central Europe, countries with less than 50\% grazing: This region has shown a rapid decline of grazing in the early 2000 s and now only a minority of the cows graze. A possible explanation is the considerable increase in average herd size per farm in the countries belonging to this region, which led to a decrease in available grazing platform per cow.

- East Europe: Data on grazing in countries in this region are limited. Even though there are differences between countries, the general pattern is that grazing has not been common practise during the last decade with obviously little change over time. Some countries like Bulgaria and Lithuania seem to be an exception. In most of East Europe, farm sizes are increasing just like in Central Europe, which might explain the low percentages of grazing.

- South Europe: Data on grazing in countries in this region are limited. Even though there are differences between countries, the general pattern is that grazing has not been common practise during the last decade with obviously little change over time. In the South, climate is an important factor. Warm and dry summers will lead to little or no grass growth which in turn leads to cattle being held indoors.

Next to the results from the WG Grazing, there are data available from 2001 onwards for three countries (Ireland, the Netherlands and Denmark) (Figure 1). It is striking that around 2000 the three countries had relatively similar rates of grazing. For Ireland, the rate has almost remained stable throughout the last 20 years, while for Denmark, it has dramatically declined. The Netherlands is in between these two countries. WG Grazing members indicate that in Ireland grazing is consistently seen as the most cost-effective method for dairy production. In Denmark, the average herd size per farm has increased considerably. The available grazing platform per cow has decreased and the corresponding percentage of grazing decreased [6]. It is expected that the percentage grazing will not decrease much further in Denmark due to the relatively high percentage of organic dairy farms. These dairy farms are obliged to graze. The trend in the Netherlands is in between Ireland and Denmark. In the Netherlands, market-driven practices led to less grazing. This dominant logic however was increasingly challenged by institutional logics centring round cultural identity and sustainability values [16]. Notable actions in the Netherlands in recent times were a Grazing Covenant signed by more than 80 parties from the full dairy chain, strengthening of advice and education, and the initiation of grazing premiums for farmers. As a result, the trend of a decrease in grazing has been reversed and there has been an 
increase in grazing since 2016. The example of the Netherlands is, however, an exception from the more general trend of less grazing in Europe.

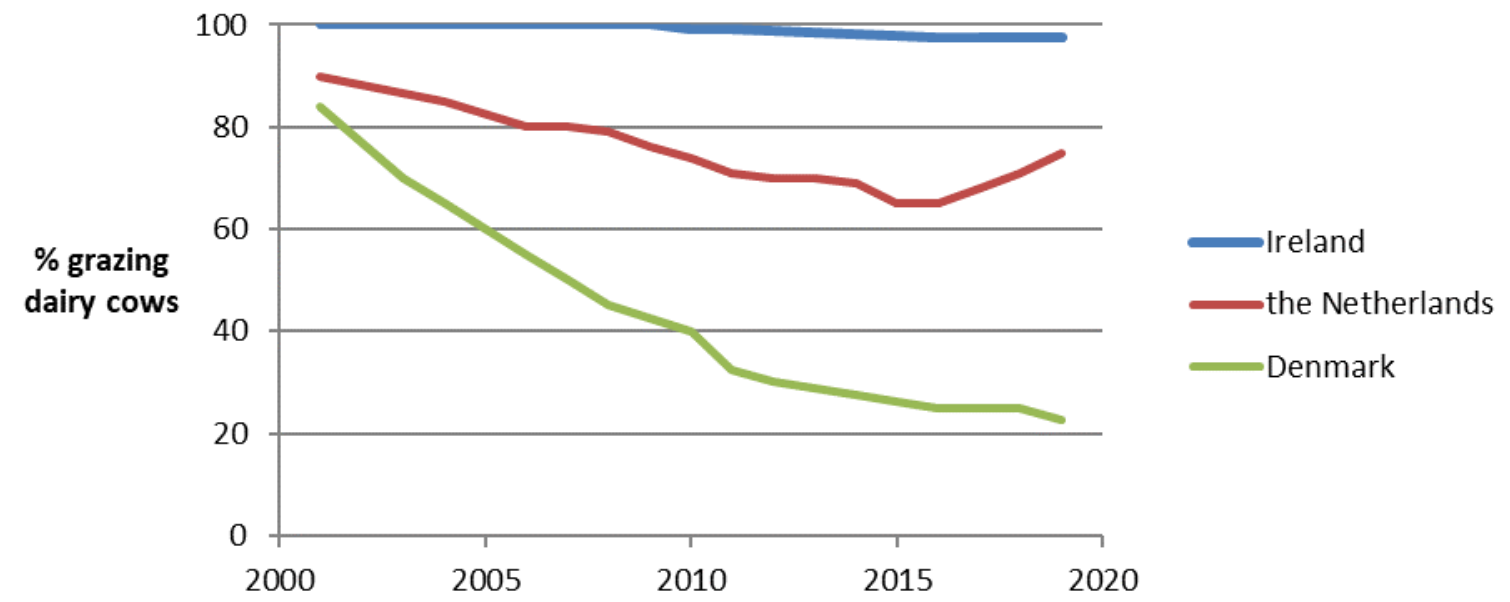

Figure 1. Grazing (\% dairy cows) in Ireland (educated guesses), the Netherlands (statistical data in 2001-2018 [15] and educated guess in 2019) and Denmark (educated guesses).

\subsection{Is Less Grazing in Europe a Problem?}

If Europe is experiencing less grazing, the question arises whether this is a problem or not. Grazing affects many aspects on a farm (e.g., economy, labour, nutrient flows). In north-western Europe, grass based dairy production is mainly seen as an economic activity with low costs and high farm profitability [3,17]. The value of grazing, however, also goes beyond the farm (e.g., landscape, environment, image of the dairy farm). Next to the farmer, there are other stakeholders that value grazing. The WG Grazing members underline the importance of grazing for a large group of stakeholders (Table 4). The importance of grazing to different stakeholder groups was also shown in the FP7 project MultiSward (www.multisward.eu). This project aimed to increase the reliance of farmers on grasslands and on multi-species swards for competitive and sustainable ruminant production systems. Active participation of stakeholders was one of the key objectives of the project. MultiSward studied the importance of the various functions of grassland for stakeholders in Europe. An on-line questionnaire in eight languages yielded almost 2000 valid responses from representatives of different stakeholder groups (farmers, governments, businesses and organisations focusing on advice, research and education). The results clearly showed that the importance of grazing was strongly recognised by all these stakeholder groups. They in fact ranked grazing the highest out of 42 predefined functions of grasslands [18].

Appreciation of grazing is based on the balance between perceived advantages and perceived disadvantages. Table 6 provides a general view of the effect of grazing based on literature. It shows a mix of advantages and disadvantages, also within themes. The advantages and disadvantages of grazing have often been discussed during WG Grazing meetings. It was concluded that they vary from farm to farm and from region to region. For many themes, the more hours of outdoor grazing, the greater the effect. Many of the advantages and disadvantages are highly dependent on the type of dairy farm. For example, the effects for a farm on sandy soil differ from those for a farm on clay or peat soil, for an intensive compared to an extensive farm and for a large compared to a small farm. Moreover, for farms with a small land base, pasture offers a completely different perspective than for farms with a large land base. Furthermore, the effect of grazing is often intertwined with an effect of farm layout. Due to the great diversity of dairy farms, it is difficult to say what 'the effect of grazing or not grazing' is on the entire dairy farm. The management of the dairy farm also plays a major role in this. A grazing dairy farmer will use targeted management to exploit the advantages of outdoor grazing as much as possible and eliminate the disadvantages of outdoor grazing as much as possible. And that is also 
what a non-grazing dairy farmer will do for his or her situation. Grazing is indeed an inseparable part of total business operations. When it comes to the overall effect of grazing, the importance attached to the various effects of grazing presented in Table 6 is very personal and depending on the types of stakeholder. The positive image of grazing may explain the higher importance of grazing for the general public as presented in Table 4 .

Table 6. Advantages and disadvantages of grazing on different themes.

\begin{tabular}{|c|c|c|}
\hline Theme & Advantages & Disadvantages \\
\hline $\begin{array}{l}\text { Animal health and } \\
\text { welfare }\end{array}$ & $\begin{array}{ll}\text { - } & \text { More possibilities for natural behaviour } \\
\text { (e.g., grazing) [19] } \\
\text { - } & \text { Lower level of mastitis [19-21] } \\
\text { - } & \text { Less risk of claw problems [19,21-24] }\end{array}$ & $\begin{array}{l}\text { - Relatively large fluctuations in the } \\
\text { composition of the ration [1] } \\
\text { Risk of disease introduction due to } \\
\text { infection with specific pathogens (e.g., } \\
\text { worms, liver fluke) [25] }\end{array}$ \\
\hline $\begin{array}{l}\text { Grass production and } \\
\text { quality }\end{array}$ & $\begin{array}{l}\text { Denser and more persistent swards } \\
\text { compared to mechanically harvested } \\
\text { swards thereby reducing the } \\
\text { requirement for sward renewal [26] }\end{array}$ & $\begin{array}{l}\text { Grazing leads to lower use of the } \\
\text { production capacity of the grassland } \\
\text { than mowing and to fluctuating grass } \\
\text { supply and grass quality [27] } \\
\text { Uncertainty about the availability and } \\
\text { quality of grass is a bottleneck for } \\
\text { livestock farmers [17] }\end{array}$ \\
\hline Quality of milk & $\begin{array}{l}\text { - Higher content of unsaturated fatty } \\
\text { acids in milk [28-30] } \\
\text { - } \quad \text { Superior processibility qualities [31,32] }\end{array}$ & $\begin{array}{l}\text { Milk quality can be more variable due to } \\
\text { the variability of grass supply and } \\
\text { quality. This can impact the production } \\
\text { of milk products, e.g., cheese yield }\end{array}$ \\
\hline Labour & $\begin{array}{l}\text { - Fewer hours of work, because the cow } \\
\text { does the work itself [33] }\end{array}$ & $\begin{array}{l}\text { - Management of grazing is more difficult } \\
\text { than management of zero-grazing [33] }\end{array}$ \\
\hline Biodiversity & $\begin{array}{l}\text { - Grazing leads to more biodiversity } \\
{[34,35]}\end{array}$ & \\
\hline $\begin{array}{l}\text { Environment (minerals, } \\
\text { greenhouse gases) }\end{array}$ & $\begin{array}{l}\text { - } \quad \text { Less ammonia emission } \\
\text { - } \quad \text { Less energy consumption } \\
\text { - } \quad \text { Less } \mathrm{CO}_{2} \text { emissions } \\
\text { - }\end{array}$ & $\begin{array}{ll}\text { - } & \text { More nitrate leaching } \\
\text { - } & \text { More denitrification } \\
\text { - } & \text { More nitrous oxide emissions } \\
\text { - } & \text { More N losses }\end{array}$ \\
\hline & {$[4,36]$} & {$[4,36]$} \\
\hline Economy & $\begin{array}{l}\text { Grazing involves lower costs; pasture } \\
\text { grass is a cheap means of production } \\
{[11,17,37,38] ; \text { a key factor affecting the }} \\
\text { economic sustainability of grass based } \\
\text { dairy production is the proportion of } \\
\text { grass in the diet }\end{array}$ & $\begin{array}{l}\text { Some regions of Europe do not have } \\
\text { satisfactory conditions to focus almost } \\
\text { exclusively on grass; climatic limitations } \\
\text { for example reduce the yield potential of } \\
\text { grassland resulting in an increase in the } \\
\text { production costs of forage [39] }\end{array}$ \\
\hline Image & $\begin{array}{l}\text { - Cows in the landscape contribute to a } \\
\text { positive image of livestock farming [40] }\end{array}$ & \\
\hline
\end{tabular}

The occurrence of grazing in Europe has changed in the last decade. Surveys on the extent of grazing in Europe show a trend of declining numbers of grazing dairy cows in favour of indoor feeding systems, although there are a few exceptions. At the same time different stakeholder groups value grazing. Therefore, the question is what the constraints to grazing are for farmers and how to overcome these constraints. 


\subsection{Constraints for Farmers and Support to Overcome These Constraints}

Focus group meetings of the WG Grazing have revealed that major constraints for farmers to practice grazing can be classified in three groups, i.e., region specific, farm specific and farmer specific constraints. Region specific constraints are those that are present and cannot be influenced by individual farmers. The only thing a farmer can do is adapt to the situation. Farm specific constraints are related to the set-up of the farm. They can be customised by the farmer, but often not in the short term. Region specific constraints and farm specific constraints can be quantified; they could be considered 'hard constraints'. Farmer specific constraints are related to the farmers themselves and to their mind-set. They deal with attitudes and perceptions. The farmer specific constraints cannot easily be quantified; they could be considered 'soft' constraints. They relate to intrinsic motivation, social pressure, image/perception of grazing and farmers skills.

The potential farmer specific constraints, identified by the WG Grazing members, could be classified according to the Theory of Planned Behaviour [41]. This theory assumes that the intention of a person to express a certain behaviour (in this case grazing) depends on (1) the attitude towards the behaviour, (2) subjective norms, and (3) perceived behavioural control. In the case of grazing, this is:

(1) The attitude of the farmer towards grazing, i.e., perception of the farmer of the costs and benefits, both monetary and non-monetary,

(2) subjective norms on grazing, i.e., cultural norms and social pressure that influence the farmer and, finally,

(3) perceived behavioural control, i.e., farmers thinking that they lack management capacities or technical skills to successfully graze their cattle.

The farmer specific constraints may amplify the farm specific constraints. For example, farmers will be reluctant to invest in grazing infrastructure (tracks, fencing, water troughs) while it is easy to invest in machinery. As mentioned by one of the members of the WG Grazing: for successful implementation, farmers' intrinsic motivation to apply a new technology is one of the basic prerequisites.

Next to constraints to grazing, focus group meetings of the WG Grazing have revealed many options to support farmers to overcome these constraints. Three areas were identified:

- Finding solutions in new knowledge, for example new technology or new grazing systems;

- Finding solutions to bring the knowledge already available to practice, for example via training and education;

- Finding solutions to reward farmers for grazing as a service to society, for example via premiums, subsidies or increased market prices.

These three solutions can logically be linked to the constraints for farmers that were identified (Table 7). Region specific and farm specific constraints can for a large part be overcome by new knowledge, e.g., new technologies or development of new grazing systems, or by bringing the already available knowledge to farmers. Farmer specific constraints are related to the mind-set of the farmers. The mind-set of the farmer can change by bringing knowledge to practice and by rewarding farmers for grazing as a service to society [12]. The first solution (knowledge) is mainly related to a change in perceived behavioural control, while the second solution affects the attitude of the farmer and/or reflects changes in subjective norms on grazing. Due to rewards, grazing will become more attractive to farmers. Rewards do not need to be necessarily monetary awards. The wide-spread assumption that farmers strive to maximize profit is often not true. They are also motivated by other aspects, like appreciation by other farmers, family, neighbours or society or by improved animal health, e.g., [42]. 
Table 7. Links between constraints of grazing and main support options to overcome these constraints.

\begin{tabular}{cccc}
\hline \multirow{2}{*}{ Type of Constraint } & \multicolumn{3}{c}{ Type of Support } \\
\cline { 2 - 4 } & New Knowledge & Spread Available Knowledge & Reward Farmers \\
\hline Region specific & $\mathrm{x}$ & $\mathrm{x}$ & \\
Farm specific & $\mathrm{x}$ & $\mathrm{x}$ & $\mathrm{x}$ \\
Farmer specific & & $\mathrm{x}$ & $\mathrm{C}$ \\
\hline
\end{tabular}

\subsection{Policy Implications}

The surveys among WG Grazing members in the period 2010-2019 provided, for the first time, an insight into the occurrence of grazing of dairy cows in Europe and created a unique dataset. There is a clear trend of less grazing in Europe. This is in contrast with the importance of grazing as described in literature and underlined by the results on importance for different stakeholder groups, including the general public and the government, from surveys and focus groups of the WG Grazing. If grazing is considered to be important by societal stakeholders, then grazing should be stimulated by policy. For effective stimulation, knowledge is needed about the constraints that farmers actually experience related to grazing and the options to overcome these constraints. The analysis, carried out by the WG Grazing, showed that there are specific types of constraints. First, there are region specific and farm specific constraints. To support farmers in overcoming those constraints, region specific knowledge is needed. This could be supported by regional governments, e.g., national and local governments can support national or local research and extension programs for this purpose. Furthermore, there are farmer specific constraints. These farmer specific constraints are the most important constraints, since the farmer is a key actor for the future of grazing. It is the farmer that decides on the overall farm system and on the day-to-day management of the farm. Farmer specific constraints are also the most difficult to overcome. Studies show that farmers are motivated by personal values, preferences, experiences and habits, e.g., [11,43]. They are also influenced by the human tendency to avoid cognitive dissonance [42,44]. Therefore, the mind-set of farmers must be considered and special attention must be paid to attitude of farmers, social norms and perceived behavioural control. For this purpose, governments could support knowledge dissemination and education and could reward farmers for grazing. Obviously, rewards can also come from the market, e.g., by rewarding added value of quality products for consumers. However, governments could play a role to reward farmers for the ecosystem services they provide to society, for example by subsidies or legislation to support grazing farmers. While formal education plays a significant part in training farmers and farmer mind-set, on-going informal learning, facilitated by extension officers from government and industry, plays a very important part in providing knowledge around grazing management and skills to overcome constraints. Indeed, the students of today are the farmers and farm advisors of the future, and as such, they determine the future of grazing. Therefore, special attention should be paid to the young farmers, since they represent the next generation of farming.

It has to be emphasized that our dataset is not a result of a thoroughly designed study. It is rather a post-hoc analysis, which means that it might not have the same analytical power compared to a fully designed study. Yet, valuable results were obtained due to the unique ensemble of methods and well documented observations/data, and due to the coverage of a period of ten years. In order to overcome constraints to grazing in the farming practice, it would be necessary to have a more interdisciplinary approach, i.e., including more explicitly people from a wider range than grassland experts, e.g., agricultural engineering, animal breeding/husbandry, agricultural economics, sociology, rural development, political science etc. Such a broader approach might have further strengthened our results and conclusions.

In the end, members of the WG Grazing stated that support is not a scientific decision, but a political decision. In the end, it is stated, "given the complexity and multifunctionality of grasslands, there cannot be only one way, one strategy for grassland management and grazing. Therefore, feasible areas should be identified and targeted where grazing can be maximised and in areas which are not suitable for grazing, other 
types of land-use should be considered sustainable." WG Grazing members state, "if grazing is not supported, the proportion of grazing dairy cows will further decline". However, a joined endeavour has the potential to make a significant difference in transforming grass-based production systems and stimulate grazing. A good example for this is the case of the Netherlands (illustrated in Figure 1). A mix of stimulating actions (a Grazing Covenant signed by more than 80 parties from the full dairy chain, the initiation of grazing premiums for farmers and a strengthening of advice and education) [16] has led to a trend change and an increase of the percentage of grazing dairy cows.

To conclude, in most countries in Europe the proportion of dairy cows grazing has been declining during the last decade. The WG Grazing identified a number of areas which can help increase levels of grazing, finding solutions in (1) new knowledge, (2) bringing the knowledge already available to practice, and (3) rewarding farmers for grazing as a service to society. In addition, the mind-set of the farmer is crucial and providing him/her with knowledge and support can have a positive impact and reverse the trend of declining grazing.

Author Contributions: Conceptualization, A.v.d.P.-v.D., D.H. and J.I.; Formal analysis, A.v.d.P.-v.D.; Investigation, A.v.d.P.-v.D.; Methodology, A.v.d.P.-v.D., D.H. and J.I.; Writing一original draft, A.v.d.P.-v.D.; Writing一review \& editing, A.v.d.P.-v.D., D.H. and J.I. All authors have read and agreed to the published version of the manuscript.

Funding: This research received no external funding.

Acknowledgments: The authors would like to acknowledge all members of the EGF WG Grazing that actively participated in surveys or focus group meetings. Without their help and input, this paper could not have been written.

Conflicts of Interest: The authors declare no conflict of interest.

\section{Appendix A}

Content of on-line survey to members of WG Grazing in 2016, 2018 and 2019 (next to the questions below specific questions related to specific WG Grazing meetings were asked)

- Your name

- Your country

- Percentage grazing for dairy cows in your country (total should be $100 \%$, educated guess is fine)

Grazing (i.e., cows have a certain number of hours grazing per year)

No grazing (i.e., cows never graze during the year)

- Please indicate the importance of grazing in your country for different groups on a scale of 1 to 10 (where 1 is unimportant and 10 is important)

For farmers

For the government

For scientists

For teachers

For students

For the general public

For you

- What is in your opinion the biggest challenge for grazing in the next decade? (asked in 2018 and 2019 only)

\section{References}

1. Huyghe, C.; De Vliegher, A.; Van Gils, B.; Peeters, A. Grasslands and Herbivore Production in Europe and Effects of Common Policies; Éditions Quae: Versailles, France, 2014; p. 287.

2. Isselstein, J.; Kayser, M. Functions of grassland and their potential in delivering ecosystem services. Grassl. Sci. Eur. 2014, 19, 199-214. 
3. Peyraud, J.L.; Van den Pol-van Dasselaar, A.; Dillon, P.; Delaby, L. Producing milk from grazing to reconcile economic and environmental performances. Grassl. Sci. Eur. 2010, 15, 865-879.

4. Thomet, P.; Cutullic, E.; Bisig, W.; Wuest, C.; Elsaesser, M.; Steinberger, S.; Steinwidder, A. Merits of full grazing systems as a sustainable and efficient milk production strategy. Grassl. Sci. Eur. 2011, 16, $273-285$.

5. Van den Pol-van Dasselaar, A.; Vellinga, T.V.; Johansen, A.; Kennedy, E. To graze or not to graze, that's the question. Grassl. Sci. Eur. 2008, 13, 706-716.

6. Kristensen, T.; Madsen, M.L.; Noe, E. The use of grazing in intensive dairy production and assessment of farmers' attitude towards grazing. Grassl. Sci. Eur. 2010, 23, 964-966.

7. Becker, T.; Kayser, M.; Tonn, B.; Isselstein, J. How German dairy farmers perceive advantages and disadvantages of grazing and how it relates to their milk production systems. Livest. Sci. 2018, 214, 112-119. [CrossRef]

8. Läpple, D.; Hennessy, T.; O’Donovan, M. Extended grazing: A detailed analysis of Irish dairy farms. J. Dairy Sci. 2012, 95, 188-195. [CrossRef]

9. Van den Pol-van Dasselaar, A.; Philipsen, A.P.; De Haan, M.H.A. The effect of social factors on the extent of grazing. Grassl. Sci. Eur. 2016, 21, 62-64.

10. Mwaijande, F.; Miller, J.; Wailes, E.; Petersen, L. The value of focus group discussions for understanding barriers to agriculture-tourism linkages in developing regions. J. Int. Agr. Extens. Educ. 2009, 16, 59-63. [CrossRef]

11. Reijs, J.W.; Daatselaar, C.H.G.; Helming, J.F.M.; Jager, J.; Beldman, A.C.G. Grazing Dairy Cows in North-West Europe: Economic Farm Performance and Future Developments with Emphasis on the Dutch Situation; LEI Wageningen UR: Wageningen, The Netherlands, 2013.

12. Van den Pol-van Dasselaar, A.; Becker, T.; Botana Fernández, A.; Hennessy, T.; Peratoner, G. Social and economic impacts of grass based ruminant production. Grassl. Sci. Eur. 2018, 23, 697-708.

13. Krueger, R.A. Focus Groups: A Practical Guide for Applied Research; Sage: Newbury Park, CA, USA, 1988.

14. Breen, R.L. A Practical Guide to Focus-Group Research. J. Geogr. Higher Educ. 2006, 30, 463-475. [CrossRef]

15. Statline CBS. Available online: https:/opendata.cbs.nl/statline/\#/CBS/nl/dataset/83953NED/table?ts= 1578161997264 (accessed on 4 January 2020).

16. Runhaar, H.; Fünfschilling, L.; Van den Pol-Van Dasselaar, A.; Moors, E.H.M.; Temmink, R.; Hekkert, M. The dynamics of socio-technical regimes examined: Regime change and sustainability transitions in Dutch dairy farming. Env. Innov. Soc. Transit.. (under review).

17. Dillon, P.; Roche, J.R.; Shalloo, L.; Horan, B. Optimising financial return from grazing in temperate pastures. In Utilisation of Grazed Grass in Temperate Animal Systems; Murphy, J.J., Ed.; Wageningen Academic Publishers: Wageningen, The Netherlands, 2005; pp. 131-147.

18. Van den Pol-van Dasselaar, A.; Goliński, P.; Hennessy, D.; Huyghe, C.; Parente, G.; Peyraud, J.L. Évaluation des fonctions des prairies par les acteurs européens. Fourrages 2014, 218, 141-146.

19. Charlton, G.L.; Rutter, S.M. The behaviour of housed dairy cattle with and without pasture access: A review. Appl. Anim. Behav. Sci. 2017, 192, 2-9. [CrossRef]

20. Washburn, S.P.; White, S.L.; Green, J.T., Jr.; Benson, G.A. Reproduction, mastitis, and body condition of seasonally calved Holstein and Jersey cows in confinement or pasture systems. J. Dairy Sci. 2002, 85, 105-111. [CrossRef]

21. Arnott, G.; Ferris, C.P.; O'Connell, N.E. Review: Welfare of dairy cows in continuously housed and pasture-based production systems. Animal 2017, 11, 261-273. [CrossRef]

22. Haskell, M.J.; Rennie, L.J.; Bowell, V.A.; Bell, M.J.; Lawrence, A.B. Housing System, Milk Production, and Zero-Grazing Effects on Lameness and Leg Injury in Dairy Cows. J. Dairy Sci. 2006, 89, 4259-4266. [CrossRef]

23. Olmos, G.; Boyle, L.; Hanlon, A.; Patton, J.; Murphy, J.J.; Mee, J.F. Hoof disorders, locomotion ability and lying times of cubicle-housed compared to pasture-based dairy cows. Livest. Sci. 2007, 125, 199-207. [CrossRef]

24. Burow, E.; Rousing, T.; Thomsen, P.T.; Otten, N.D.; Sørensen, J.T. Effect of grazing on the cow welfare of dairy herds evaluated by a multidimensional welfare index. Animal 2013, 5, 834-842. [CrossRef]

25. Borgsteede, F.H.M.; Van der Burg, W.P.J. Worm burdens in cows II. An analysis of the population of nematodes in the abomasa of adult dairy cows. Vert. Para. 1982, 10, 323-330. [CrossRef]

26. Johnson, I.R.; Parsons, A.J. Use of a model to analyse the effects of continuous grazing managements on seasonal patterns of grass production. Grass Forage Sci. 1985, 40, 449-458. [CrossRef] 
27. Peyraud, J.L.; Delagarde, R. Managing variations in dairy cow nutrient supply under grazing. Animal 2011, 7, 57-67. [CrossRef] [PubMed]

28. Elgersma, A. Grazing increases the unsaturated fatty acid concentration of milk from grass-fed cows: A review of the contributing factors, challenges and future perspectives. Eur. J. Lipid Sci. Technol. 2015, 117, 1345-1369. [CrossRef]

29. Wyss, U.; Munger, A.; Collomb, M. Variation of fatty acid content in grass and milk during the grazing season. Grassl. Sci. Eur. 2010, 15, 422-424.

30. O'Callaghan, T.F.; Hennessy, D.; McAuliffe, S.; Kilkawley, K.N.; O’Donovan, M.; Dillon, P.; Ross, R.P.; Stanton, C. Effect of pasture versus indoor feeding systems on raw milk composition and quality over an entire lactation. J. Dairy Sci. 2016, 99, 9424-9440. [CrossRef]

31. Magan, J.B.; Tobin, J.T.; O'Callaghan, T.F.; Kelly, A.L.; Fenelon, M.A.; Hennessy, D.; McCarthy, N.A. Physicochemical properties of whole milk powder derived from cows fed pasture or total mixed ration diets. J. Dairy Sci. 2019, 102, 9611-9621. [CrossRef]

32. Gulati, A.; Hennessy, D.; O’Donovan, M.; McManus, J.J.; Fenelon, M.A.; Guinee, T.P. Dairy cow feeding system alters the characteristics of low-heat skim milk powder and processability of reconstituted skim milk. J. Dairy Sci. 2019, 102, 8630-8647. [CrossRef]

33. Hennessy, D.; Delaby, L.; Van den Pol-van Dasselaar, A.; Shalloo, L. Possibilities and constraints for grazing in high output dairy systems. Grassl. Sci. Eur. 2015, 20, 151-162.

34. Klimek, S.; Richter gen. Kemmermann, A.; Hofmann, M.; Isselstein, J. Plant species richness and composition in managed grasslands: The relative inportance of field management and environmental factors. Biol. Conserv. 2007, 134, 559-570. [CrossRef]

35. Metera, E.; Sakowski, T.; Słoniewski, K.; Romanowicz, B. Grazing as a tool to maintain biodiversity of grassland-A review. Anim. Sci. Pap. Rep. 2010, 28, 315-334.

36. Meul, M.; Van Passel, S.; Fremaut, D.; Haesaert, G. Higher sustainability performance of intensive grazing versus zero-grazing dairy systems. Agron. Sustain. Dev. 2012, 32, 629-638. [CrossRef]

37. Shalloo, L. Milk Production Costs-Can We Compete? In Proceedings of the Teagasc National Dairy Conference, Mullingar, Ireland, 18 November 2009; pp. 19-38.

38. Finneran, E.; Crosson, P.; O'Kiely, P.; Shalloo, L.; Forristal, D.; Wallace, M. Stochastic simulation of the cost of home-produced feeds for ruminant livestock systems. J. Agric. Sci. 2012, 150, 123-139. [CrossRef]

39. Peratoner, G.; De Ros, G.; Senoner, J.L.; Figl, U.; Florian, C. Effect of slope and altitude on the costs of forage production in mountain areas. Grassl. Sci. Eur. 2017, 22, 215-217.

40. Boogaard, B.K.; Bock, B.B.; Oosting, S.J.; Wiskerke, J.S.C.; Van der Zijpp, A. Social Acceptance of Dairy Farming: The Ambivalence Between the Two Faces of Modernity. J. Agric. Environ. Ethics 2011, 24, $259-282$. [CrossRef]

41. Ajzen, I. The theory of planned behavior. Organ. Behav. Hum. Dec. 1991, 50, 179-211. [CrossRef]

42. Kristensen, E.; Jakobsen, E.B. Challenging the myth of the irrational dairy farmer; understanding decision-making related to herd health. N. Zeal. Vet. J. 2011, 59, 1-7. [CrossRef]

43. Baur, I.; Dobricki, M.; Lips, M. The basic motivational drivers of northern and central European farmers. J. Rural Stud. 2016, 46 (Suppl. C), 93-101. [CrossRef]

44. Festinger, L. Cognitive dissonance. Sci. Am. 1962, 207, 93-107. [CrossRef]

(C) 2020 by the authors. Licensee MDPI, Basel, Switzerland. This article is an open access article distributed under the terms and conditions of the Creative Commons Attribution (CC BY) license (http://creativecommons.org/licenses/by/4.0/). 